\title{
Consumer Behavior Model Based on Integration of Food Safety and Health Consciousness in Padang City
}

\author{
Skunda Diliarosta*, Arief Muttaqiin, Rehani Ramadhani
}

\section{Skunda Diliarosta*, Arief Muttaqiin, Rehani Ramadhani}

Department of Science Education, Universitas Negeri Padang, INDONESIA.

\section{Correspondence}

\section{Skunda Diliarosta}

Department of Science Education, Universitas Negeri Padang, INDONESIA

E-mail: skunda@fmipa.unp.ac.id

History

- Submission Date: 29-09-2020;

- Review completed: 21-10-2020;

- Accepted Date: 02-11-2020.

DOI : 10.5530/pj.2021.13.30

Article Available online http://www.phcogj.com/v13/i1

\section{Copyright}

(C) 2021 Phcogj.Com. This is an openaccess article distributed under the terms of the Creative Commons Attribution 4.0 International license.

\begin{abstract}
The growing number of food poisoning cases that occurred in Padang City in 2017-2018 shows that various regulations that have been made by the government have not been able to stop producers and traders from using hazardous substances in food. Therefore, research is needed that aims to form a model of consumer behavior that focuses on consumer awareness of the choice of food consumed through the integration of health awareness and food safety. This study is a Research and Development study using the ADDIE approach. Based on the results of the analysis conducted at the Padang city market, it shows that the behavior of vegetable consumers in the city of Padang tends not to care about the dangers of chemical residues in pesticides and fertilizers used by vegetable farmers. Based on the existing need to support the formation of an integrated consumer behavior model for food safety and health awareness, it is by providing guidance in choosing healthy vegetables and by distributing leaflets on the benefits of vegetables. And to encourage consumer awareness, motivation is given to a healthy lifestyle so that families avoid the dangers of food poisoning through social media. This study produces a Conceptual Design of Consumer Behavior Model based on Integration of Food Safety and Health Consciousness in Padang City. From the results of the model test, the F significance value of $0.000(p<0.05)$ can be concluded that the hypothesis is accepted, meaning that food selection variables, health awareness and food safety have a significant effect on consumer behavior together.
\end{abstract}

Key Words: Vegetable Consumers, Consumer Behavior, Food Safety, Pasar Raya Padang.

\section{INTRODUCTION}

A consumer is someone who uses, uses, consumes goods and services, not someone who distributes or distributes or produces or produces them. Consumer behavior is the action that is directly involved in obtaining, consuming, and spending products and services, including the decision process that precedes and follows these actions ${ }^{2}$. The tendency of consumers to choose food only sees the physical condition ${ }^{3}$.Schiffman and Kanuk (2006), define consumer behavior as behavior shown by consumers in finding, buying, using, evaluating, and spending products or services that they hope will satisfy their needs ${ }^{4}$.

Food is a basic human need that is very important for memaintain body health, growth, maintenance and improvement of health status and community intelligence ${ }^{5}$. Food safety has been regulated in such a way as in statutory regulations, namely Law No. 18 of 2012 concerning Food; Law Number 8 of 1999 concerning Consumer Protection; and Government Regulation Number 28 of 2004 concerning Food Quality and Nutrition ${ }^{6}$. However, food safety problems continue to occur and become a world concern because hundreds of millions of people are reported to be suffering from diseases caused by food poisoning.

The number of cases of food poisoning that occurred in Indonesia from 2014 to 2018. In the province of West Sumatra itself, food poisoning cases have been included in the extraordinary incidence (KLB) category.Cases of food poisoning (Foodborne disease) occurred in 2017-2018 . Various laws and government regulations that have been made by the government are still unable to move consumers to choose healthy foods for consumption ${ }^{8}$. Poisoning is a condition when the body experiences vomiting, diarrhea or nausea after consuming food ${ }^{9}$. Food poisoning is a symptom caused by consuming food that is poisonous or contaminated with bacteria or microorganisms ${ }^{10}$.

Padang city is the capital of West Sumatra, which is located in the west of the island of Sumatra. The city has the largest trading center viz Pasar Raya Padang. In addition, trading activities in Padang are also supported by 16 small markets scattered throughout the city, nine of which are owned by the Padang City Government, namely Alai Market, Lubuk Buaya Market, Simpang Haru Market, Siteba Market, Bandar Buat Market, Belimbing Market, Bungus Market, Ulak Karang Market and Tanah Kongsi Market.

Based on the results of preliminary observations of vegetable consumers in the main market in Padang City, the attitudes of market consumers do not pay attention to the health and safety of the vegetables they buy.

The consumer view of the Padang highway market is still conventional, it has not led to modern consumers who are concerned with safety and health compared 
to price. Judging from the situation when consumers buy vegetables. Consumers are more interested in buying vegetables that look clean, attractive and without caterpillars and at low purchase prices. Yet if you look more closely, the pesticide content that settles on these vegetables is very much. Farmers spray various types of pesticides the day before harvesting.KejaThe dian shows that the various regulations that have been made have not been able to stop producers and traders from using hazardous substances in food. Therefore, we need a model that is able to shape and accustom people to behave more consciously and caring about the food they consume, so that their rights as consumers to get safety and comfort are realized. So, a study was carried out that aims to form a model that focuses on consumer awareness of the choice of food they consume through the integration of health awareness and food safety. So that a model of consumer behavior is made that can be used as a solution to overcome the problems above and is very important to do. This consumer behavior model is named "Consumer Behavior Model Based on Food Safety and Health Consciousness". This model is integrated by incorporating elements of food safety (Food Safety) and elements of health awareness, so that the danger of food poisoning will be minimized by the awareness of the consumers themselves. Modeling through the integration of food safety with health awareness has never been done. This integration was chosen because the level of health awareness and attention to food safety would influence attitudes and interests in buying healthy food11. so that the danger of food poisoning will be minimized by the awareness of the consumers themselves. Modeling through the integration of food safety with health awareness has never been done. This integration was chosen because the level of health awareness and attention to food safety would influence attitudes and interests in buying healthy food11. so that the danger of food poisoning will be minimized by the awareness of the consumers themselves. Modeling through the integration of food safety with health awareness has never been done. This integration was chosen because the level of health awareness and attention to food safety would influence attitudes and interests in buying healthy food ${ }^{11}$.

\section{Model consumer behavior}

Jisana mentions that everyone involved in the consumption process is a consumer $^{12}$. In Law Number 8 of 1999 article 1 paragraph 2 concerning consumer protection, that consumers are users of goods or services available in society, both for the interests of themselves, their families, other people, and other creatures and not for sale. Consumer behavior is the study of processes involved when individuals or groups choose, buy, use, or manage products, services, ideas or experiences to satisfy consumer needs and wants ${ }^{13}$.

\section{Food safety}

In Law Number 7 of 1996 explains that food is everything that comes from biological sources and water, both processed and unprocessed, which is intended as food or beverage for human consumption, including food additives, food raw materials, and materials. others that are used in the process of preparing, processing and or making food or beverages. Furthermore, in Law Number 18/2012, it is mandated to ensure that the available food must be sufficient, both in quantity and quality, safe, diverse, nutritious, equitable and affordable and does not conflict with the religion, belief and culture of the community, in order to live. healthy, active, and productive in a sustainable manner. This is in accordance with the FAO and WHO declarations which emphasize that every individual has the right to food with adequate and safe nutritional value. Food safety is closely related to health. If security is not maintained, it can cause health problems and even death ${ }^{14}$.

\section{RESEARCH METHODS}

This research was conducted in the city of Padang. The choice of this location is because the city of Padang is the provincial capital which is the center of community activity, consequently encouraging food producers to continue to develop so that this city is rich in food variations. This study uses the ADDIE model. The final objective of this study is to create a model of consumer behavior that focuses on consumer awareness of the choice of food consumed through the integration of health and food safety awareness, which is measured by changes in community behavior in the city of Padang. This research was conducted in a market located in the city of Padang, namely Impress Block II market.

Population is a generalization area consisting of objects or subjects that have certain qualities and characteristics that are determined by the researcher for study and then draw conclusions. The population in this study are consumers who purchase vegetables at the main market in Padang city.

The research instrument used in this study was a questionnaire consisting of 3 variables. The variables are food selection variables, health awareness variables and food safety variables.

In this behavior model, an outreach is carried out to consumers by providing brochures, guidance and guidance to consumers so that consumers do not choose vegetables to be consumed by their families. So that by providing guidance and guidance to consumers, consumer awareness has begun to focus on awareness of health and food safety. The expected result of this guidance is that people are starting to be selective in choosing vegetables, which can improve the quality of life of the community, improve public health and be free from pesticide residues.

\section{RESULTS AND DISCUSSION}

Padang city market is a traditional market center located in the center of Padang. Due to the location of the market which is in the center of Padang, this market is very strategic to visit. Padang city market has merchant stalls, these stalls can meet the needs of clothing, food and shelter for the people of Padang city and its surroundings. The Padang Raya Vegetable Kiosk is located in the Impress block II building, which is on Ps. New. This market sells various kinds of vegetables from various regions.

This research was conducted by surveying the condition of market consumers who shop for vegetables every day. This research was conducted by interviewing consumers and distributing questionnaires. The interview is one of the data collection techniques in the form of information from a source by asking questions. However, consumer concern is not fully within the consumer. They do not heed the harm they will face when consuming unhealthy vegetables or containing pesticides.

Interviews were conducted with vegetable consumers who were shopping for vegetables at the Padang city market. This interview is intended to obtain information related to consumer behavior in choosing healthy vegetables for their families.

In addition to conducting interviews with consumers, the research team also distributed questionnaires whose aim was to see consumer behavior, so that the survey that had been conducted became a benchmark in modeling consumer behavior.

Purchasing decisions are consumer decisions regarding preferences for brands that are in the set of choices ${ }^{17}$. Decision making or deciding means choosing one of two or more alternatives. A person is faced with the process of making a buying decision when he has to choose at least two alternatives, buy or not buy. Decision making can also be interpreted as identifying and selecting various solutions that lead to a desired end result.

In purchasing vegetables, consumers have their own characteristics in choosing vegetables to consume. Most consumers prefer vegetables 
Table 1: Table normality test results.

\begin{tabular}{ccccc}
\hline Variable & Pre Test & Post Test 1 & Poet Test 2 & P Value \\
\hline $\begin{array}{c}\text { Food } \\
\begin{array}{c}\text { Selection } \\
(\mathrm{X} 1)\end{array}\end{array}$ & .281 & .166 & -281 & .100 \\
$\begin{array}{c}\text { Health } \\
\text { Awareness } \\
(\mathrm{X} 2)\end{array}$ & .368 & .186 & -368 & .090 \\
$\begin{array}{c}\text { Food Safety } \\
(\mathrm{X} 3)\end{array}$ & .411 & .219 & -.411 & .000 \\
\hline
\end{tabular}

Table 2: Multiple Regression Table.

\begin{tabular}{|c|c|c|c|c|}
\hline \multicolumn{5}{|c|}{ Model Summary } \\
\hline Model & $\mathbf{R}$ & R Square & $\begin{array}{l}\text { Adjusted } \\
\text { Square }\end{array}$ & $\begin{array}{l}\text { R Std. Error of the } \\
\text { Estimate }\end{array}$ \\
\hline 1 & $.776 a$ & .602 & .582 & 4,43099 \\
\hline
\end{tabular}

Table 3: Table of F test results.

\begin{tabular}{|cccccc|}
\hline Model & $\begin{array}{c}\text { Sum of } \\
\text { Squares }\end{array}$ & df & Mean Square & F & Sig. \\
\hline Regression & 1810,809 & 3 & 603,603 & 30,743 & $.000 a$ \\
\hline Residual & 1197,653 & 61 & 19,634 & & \\
Total & 3008,462 & 64 & & & \\
\hline
\end{tabular}

a. Predictors: (Constant), Food Selection, Health Awareness, Food Safety

b. Dependent Variable: Consumer Behavior

Table 4: Table of T test results.

\begin{tabular}{cccc}
\hline Constants and Variables & Regression Coefficient & significant & Decision \\
\hline Constant (a) & 8,804 & .439 & - \\
Food Selection (X1) & -.030 & .698 & Ho was rejected \\
Health Awareness (X2) & .189 & .049 & Ho accepted \\
Food Safety (X3) & .740 & .000 & Ho was rejected \\
F count & 30,743 & .000 & Decent Model \\
Adjusted R2 & & .582 & \\
\hline
\end{tabular}

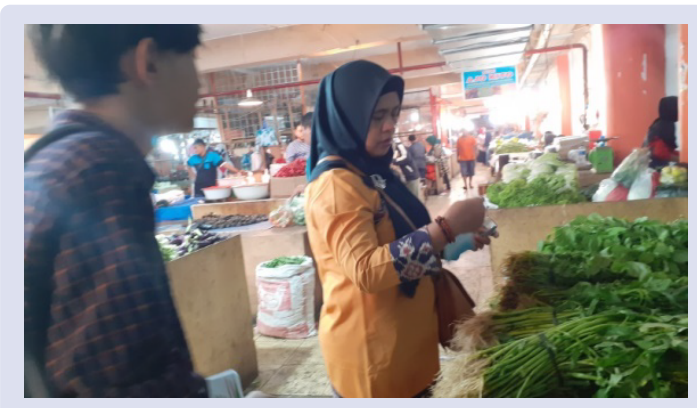

Figure 1: Interview.

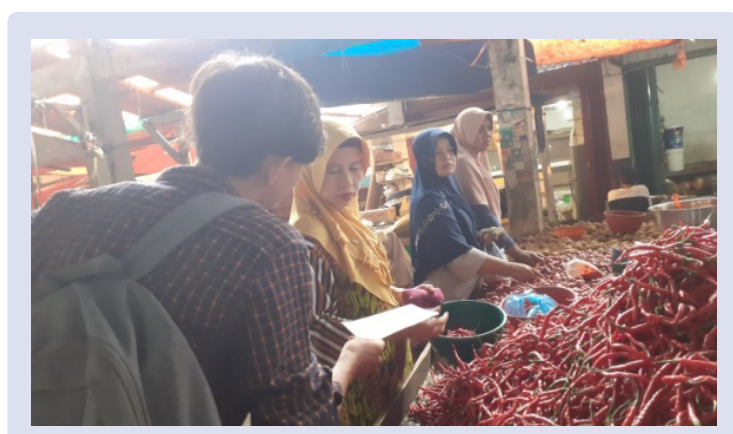

Figure 2: Distribution of questionnaire questionnaires 
with an attractive appearance and consumers' perception of vegetables is still very ancient, namely all vegetables are the same, their nutritional content is the same. However, behind all that, there is a detrimental impact on consumers when the vegetables they consume are exposed to chemical fertilizer and pesticide residues.

This research has produced a Conceptual Design of Consumer Behavior Model based on Integration of Food Safety and Health Consciousness in Padang City. As illustrated below:

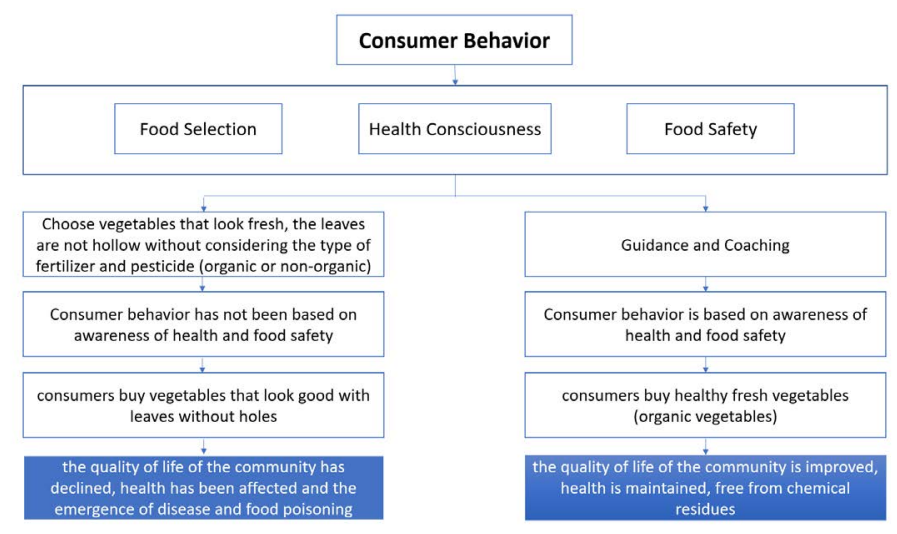

Conceptual Model of Consumer Behavior based on Integration of Food Safety and Health Consciousness in Padang City

The design of a Consumer Behavior Model based on the Integration of Food Safety and Health consciousness in Padang City is based on an analysis of the needs and sources regarding the formation of consumer behavior. The results of the analysis show that the behavior of vegetable consumers in Padang cities tends to be ignorant of the dangers of chemical residues in pesticides and fertilizers used by vegetable farmers. The market does not have special stalls for organic vegetable traders so that it does not motivate organic vegetable traders and farmers to provide organic vegetables. The unavailability of organic vegetable choices in the market makes consumers not care whether they have bought vegetables that are good for health or on the contrary, it actually adds to the accumulation / buildup of toxins in their family's body. The alternative trend is that consumers choose only fresh and light-colored vegetables without knowing that behind the fresh vegetables there are chemical residues from agricultural products using chemical fertilizers and pesticides. As a result, the quality of life decreases, health decreases, various types of food poisoning increase and can even cause death.

\section{DATA ANALYSIS}

\section{Normality test}

The significance value obtained based on the komogrov-simornov obtained a significance value more than 0.05 . The calculated $\mathrm{D}$ value is 0.1 and the $D^{*}$ value $(\alpha=0.05, n=93)$ obtained from the statistical table is 0.137 . Therefore $0.1<0.137$ or $\mathrm{D}<\mathrm{D}$ * then Ho is accepted and in accordance with the basic decision making in the normality test, it can be concluded that the data is normally distributed. thus, the assumptions or normality requirements in the regression model are met. The results of the normality test can be seen in the table below.

\section{Multiple regression}

The value of the correlation or relationship (R) between the food selection score (X1), health awareness (X2) and food safety (X4) on the consumer behavior variable $(\mathrm{Y})$ is 0.776 and the percentage of influence of variable $\mathrm{X}$ on consumer behavior variables $(\mathrm{Y})$ The socalled coefficient of determination which is the result of measurement $\mathrm{R}$. So that the coefficient of determination of $\mathrm{R}$ square is 0.602 which implies that the effect of the independent variable $\mathrm{X}$ on the dependent variable of consumer behavior $(\mathrm{Y})$ is $60.2 \%$.

\section{Ftest}

The F significance value obtained is 0.000 ( $\mathrm{p}<0.05$ ), it can be concluded that the hypothesis is accepted, meaning that the variable food selection (X1), health awareness (X2) and food safety (X) 3 have a significant effect on behavior simultaneously. consumer (Y). F test results can be seen in the table below.

\section{Ttest}

The significance value for the food selection variable (X1) is 0.698 ( $\mathrm{p}>0.05$ ), therefore the hypothesis is rejected, meaning that the food selection variable (X1) has no significant effect on the consumer behavior variable $(\mathrm{Y})$. The significance value for the health awareness variable (X2) is 0.049 ( $\mathrm{p}<0.05)$, therefore the hypothesis is accepted, meaning that the health awareness variable (X2) has a significant effect on the consumer behavior variable $(\mathrm{Y})$. The significance value for the food safety variable $(\mathrm{X} 3)$ is $0.000(\mathrm{p}<0.05)$, therefore the hypothesis is rejected, meaning that the food safety variable (X3) has no significant effect on the consumer behavior variable $(\mathrm{Y})$. The results of the T test can be seen in the table below.

\section{CONCLUSIONS}

Based on the results of the research conducted, it can be concluded that the Padang market consumers, still do not prioritize health and food safety, in purchasing vegetables consumers prefer vegetables with smooth skin conditions, bright and fresh colors. So that a model of consumer behavior is created by integrating elements of food safety and health awareness to improve consumer mindsets in choosing healthy vegetables for families. From the results of the model test, the F significance value of $0.000(\mathrm{p}<0.05)$ can be concluded that the hypothesis is accepted, meaning that the variable food selection (X1), health awareness (X2) and food safety (X3) have a significant effect on consumer behavior $(\mathrm{Y})$.

\section{SUGGESTION}

Based on the current situation, consumer demand for vegetables is increasing, due to the emergence of healthy lifestyles by some consumers. However, consumers also need to know which vegetables are healthy to eat and free from pesticide residues, by paying attention to the characteristics of vegetables without pesticides and consuming organic vegetables. Consumers must also pay attention to the freshness of the vegetables consumed. In addition, producers must also pay attention to the impact of the use of fertilizers and pesticides on the health of consumers, because excessive use of fertilizers and pesticides will increase the danger of food poisoning and even death.

\section{REFERENCES}

1. Zazili, A and Hartono. 2016. Model of Consumer Empowerment against Hazard Threats of Food Products Contaminated with Toxic Hazardous Materials in Lampung Province. IUS QUIA IUSTUM Legal Journal. Vol. 3: 391 - 414.

2. Engel JF; Blackwell RD and PW Miniard. 1995. Consumer Behavior. Translation of Consumer Behafior. Six Edition. The Dryden Press, Chicago. Binarupa Script: Jakarta.

3. Diliarosta, skunda. 2016. The Model Of The Establishment Of Environmental Behavior by Vegetable Farmer in The Padang City. ASEAN Comparative Education Reserac Network Conference: 1496-1503.

4. Hasan, Ali. 2013. Marketing and Choice Cases, Consumer Behavior Analysis CAPS First Printing: Yogyakarta.

5. Diliarosta, skunda. 2013. Content of Cadmium (CD) in Spinach with Heavy Metal Contaminated Water. Journal of Applied Science and Technology. Vol. 7.

6. Kusumawardani, V and Rohmah, U. 2018. Adoption of Food Safety Counseling Innovations for the Food and Drug Administration of the Republic of Indonesia. Journal of Communication and Media Studies. Vol. 22 (1): $45-64$ 
7. Baand Food and Drug Supervisory Agency [BPOM]. 2018. Annual Report 2017.

8. Diliarosta, skunda. 2018. The Influence of Environmental Health Knowledge, Life Motivation, Health, and Family Environment on Behavior of Eco-Friendly Vegetable Farmers in Padang City. Science National Seminar IX: 346-353.

9. Rahayu WP, Anggitasari, Ratnasari Y. 2014. The Effect of School Food Safety Programs on Knowledge of Snack Food Vendors and Elementary School Students (Effect of Food Safety Program in Elementary Schools on the Knowledge Improvement of Food Vendors and Students). Journal of Food Quality. Volume 1 (2): 73-80.

10. 13Zazili, A and Hartono. 2016. Model of Consumer Empowerment against Hazard Threats of Food Products Contaminated with Toxic Hazardous Materials in Lampung Province. IUS QUIA IUSTUM Legal Journal. Vol. 3: 391 - 414.
11. Shaharudin, MR., JJ. Pani, SW. Mansor, SJ. Elias, and DM. Sadek. 2010 Purchase Intention of Organic Food in Kedah, Malaysia: A Religious Overview. International Journal of Marketing Studies. 2 (1): 96-103.

12. Jisana TK 2014. Consumer Behavior Models: An Overview. Sai Om Journal Of Commerce And Management. Volume 1, Issues 5.ISSN 2347-7536.

13. Hasan, Ali. 2013. Marketing and Choice Cases, Consumer Behavior Analysis. CAPS First Printing: Yogyakarta.

14. Baand Food and Drug Supervisory Agency [BPOM]. 2017. Annual Report 2016.

15. Sugiyono.2007. Statistics for Research. Bandung: Alfabeta.

16. Kotler and Armstrong. 2008. Marketing Principles. Volume 1 and 2, Issue 12 , Erlangga. Jakarta.

17. Kreitner, Robert. 2005. Organizational Behavior. Four Salemba. Jakarta.

\section{GRAPHICAL ABSTRACT}
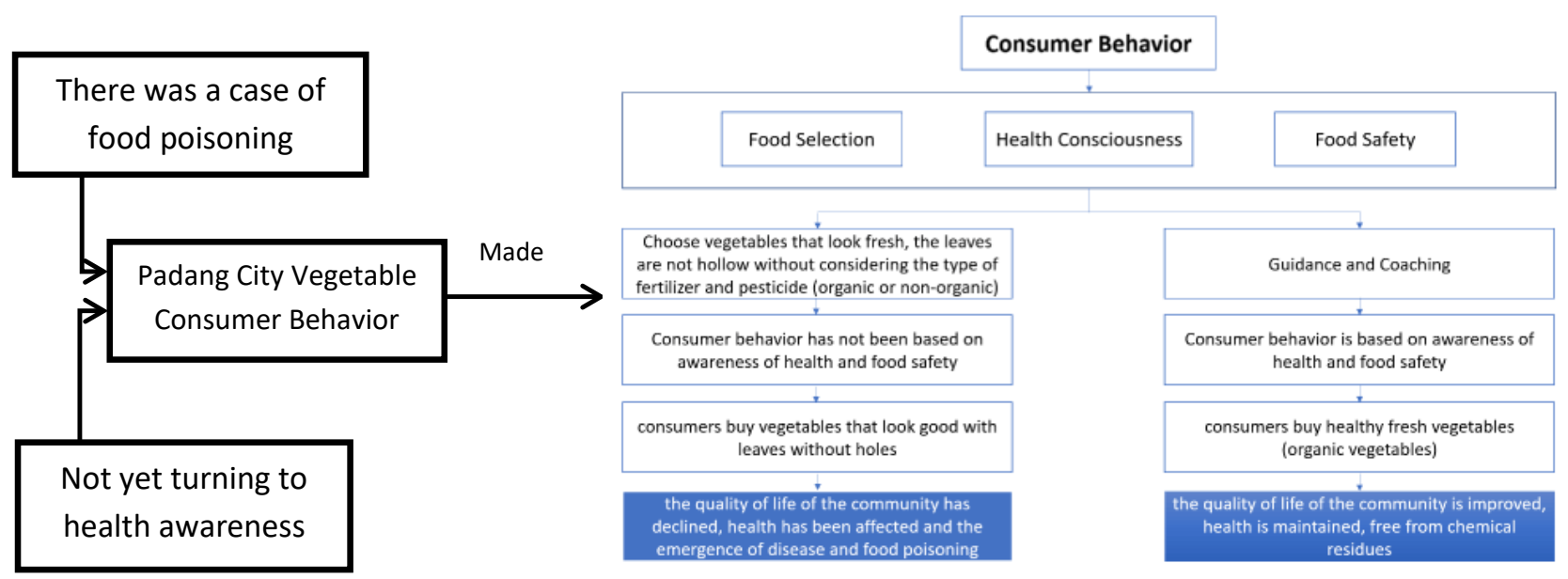

\section{ABOUT AUTHORS}

- Dr. Skunda Diliarosta, M.Pd; Currently as lecturer at Mathematics and Science Faculty, Padang State University. Doctoral program graduated from Padang State University. The research and expertise are in environmental and science education. One of the new research is about the effect of agricultural extension for improvement environmental behavior by vegetable farmer.

- Arief Muttaqiin, M.Pd; is a lecturer at the Department of Science Education, Universitas Negeri Padang. The research topics he has worked on are STEM Education, Ethnoscience, and Integrative Natural Sciences Content. Currently, he is actively developing teaching materials related to natural sciences and studying them from several perspectives such as on the aspects of STEM, ethnoscience, and contextual / socio-scientific issues.

- Rehani Ramadhani; Students of Natural Science Education Padang State University 2017, Graduated from ES 24 Ujung Gurun, JHS 13 Padang and SHS Ekasakti Padang. The research have been followed about Integration of Food safety and health consciousness in Padang and actives to be part of girlscout UNP.

Cite this article: Diliarosta S, Muttaqiin A, Ramadhani R. Consumer Behavior Model Based on Integration of Food Safety and Health Consciousness in Padang City. Pharmacog J. 2021;13(1): 212-6. 